\title{
Limonene, (+/-)-
}

National Cancer Institute

\section{Source}

National Cancer Institute. Limonene, (+1-)-. NCI Thesaurus. Code C61709.

A racemic mixture of limonene, a natural cyclic monoterpene and major component of the oil extracted from citrus rind with chemo-preventive and antitumor activities. The metabolites of DL-limonene, perillic acid, dihydroperillic acid, uroterpenol and limonene 1,2-diol are suggested to inhibit tumor growth through inhibition of p21-dependent signaling, induce apoptosis via the induction of the transforming growth factor betasignaling pathway, inhibit post-translational modification of signal transduction proteins, result in G1 cell cycle arrest as well as cause differential expression of cell cycle- and apoptosis-related genes. 